\title{
МИСТЕЦТВОЗНАВСТВО
}

\author{
DOI: https://doi.org/10.32839/2304-5809/2021-3-91-9 \\ УДК 786.2.087.4
}

Гулик В.С.

Київська муніципальна академія танцю імені Сержа Лифаря

\section{КОЗАЦЬКИЙ ТАНЕЦЬ У ТВОРАХ УКРАЇНСЬКИХ ПИСЬМЕННИКІВ}

\begin{abstract}
Анотація. У статті досліджено проблему походження та розвитку козацького танцю, розкривається художньо-творчий потенціал українського козацького танцю в мистецьких творах літератури. Проаналізовано відомості про танцювальну культуру українського народу описану в художніх джерелах як давньої, так і сучасної літератури. Показано чинники фрормування козацького танцю, а також роль і значення в цьому процесі Запорозької Січі. Стаття присвячена висвітленню традиційних елементів козацької видовищної хореографрії та святково-розважальної культури у контексті історичної творчої спадщини української писемності. Досліджено роботу під назвою «Запорізька січ - колиска козацького танцю» Олександра Колоска. Вказано імена дослідників українського народного танцю. Надано огляд творів українських письменників та поетів. Описано характерні риси притаманні козацькому танщю. Висвітлено одні з найяскравіших згадок про танець козаків в українській літературі.
\end{abstract}

Ключові слова: український народ, козацький танець, запорозькі козаки, історія, культура, українські письменники, література.

Gulik Victoria

Kyiv Municipal Dance Academy named after Serge Lifar

\section{COSSACK DANCE IN THE WORKS OF UKRAINIAN WRITERS}

Summary. The article examines the problem of the origin and development of Cossack dance, reveals the artistic and creative potential of Ukrainian Cossack dance in works of literature. Information about the dance culture of the Ukrainian people described in artistic sources of both ancient and modern literature is analyzed. The factors of formation of Cossack dance, as well as the role and significance of the Zaporozhian Sich in this process are shown. The article is devoted to the coverage of traditional elements of Cossack entertainment choreography and festive and entertaining culture in the context of the historical creative heritage of Ukrainian literature. The work entitled "Zaporizhzhya Sich - the cradle of Cossack dance" by Oleksandr Kolosko was studied. The names of researchers of Ukrainian folk dance are indicated. An overview of the works of Ukrainian writers and poets is provided. Characteristic features inherent in the Cossack dance are described. Some of the brightest mentions of the Cossack dance in Ukrainian literature are highlighted. Much information about the dance culture of the Ukrainian people is hidden in the artistic sources of both ancient and modern literature, but none of the scholars undertook to study this richness of national culture. The dance culture of the Ukrainian people is reflected in the works of art. They deserve more careful study, because they are a source of knowledge about the life of the Ukrainian people and the richness of its spiritual culture. Oleksandr Kolosok gathered in his work "Zaporizhzhya Sich - the cradle of Cossack dance" all the components of the life of the Ukrainian Cossacks together. It is remarkable that he draws attention to the mention of Cossack life and leisure in fiction. Thanks to them you can find wonderful images of Cossacks and unique performance of Cossack dance movements for stage productions. The issue of Cossack dance in the works of Ukrainian writers still remains poorly understood. Despite a fairly large legacy of research on Ukrainian works in various arts, there is almost no research on the work of written heritage in the field of choreography. Analysis of disparate sources of Ukrainian folk dance of past centuries will allow modern researchers, folklorists and ethnographers to discover the whole world of folk dance, which in the past brought glory to our people far beyond Ukraine, and is now being forgotten.

Keywords: Ukrainian people, Cossack dance, Zaporozhian Cossacks, history, culture, Ukrainian writers, literature.

Постановка проблеми. На сьогоднішній день тема козацтва не втрачає актуальності і ми часто можемо спостерігати постановки різноманітних козацких танців, як в репертуарі професійних танцювальних колективів, так і самодіяльних. Це «Запорожці» та «Повзунець» у виконанні Національного заслуженого академічного ансамбль танщю України імені Павла Вірського, вокально-хореографрічна композиція «Запорожці» у виконанні Національного заслуженого академічного українського народного хору України імені Григорія Верьовки, "Героїчна козацька сюїта» у виконанні студентів та учнів Київської муніципальної академії танщю імені Сержа Лифаря та багато інших.
Аналіз останніх досліджень і публікацій. Ми знаємо багато дослідників народного танцю, зокрема українського. Це Василь Верховинець i Василь Авраменко, Андрій Гуменюк і Кім Василенко, Клара Балог і Павло Вірський та багато інших. Вони ставили собі за мету віднайти і зберегти для майбутніх поколінь історію виникнення та розвитку українського танцю, особливості його виконання, передати своїм наступникам кращі зразки української народної творчості. Завдяки роботам дослідників ми можемо простежити еволюцію виконання деяких танцювальних рухів, ознайомитись 3 танцювальною культурою різних регіонів України і тим самим дізнатись 
про звичаї, побут та культуру наших предків. В роботах дослідників українського народного танцю можна зустріти не тільки описи українських танців, традицій і обрядів. Значний вплив на нематеріальну культуру наших предків мали й історичні події різних часів. Спосіб життя та обставини також накладали свій слід на формування культури і звичаїв українського народу.

Виділення не вирішених раніше частин загальної проблеми. Питання козацького танцю в творах українських письменників й досі залишається малодослідженою. Попри достатньо велику спадщину досліджень українських творів у різних видах мистецтва, майже відсутні дослідження творчості письменної спадщини в галузі хореографрії. Аналіз розрізнених джерел з українського народного танцю минулих століть дасть змогу сучасним дослідникам-фрольклористам та етнографрам відкрити цілий світ народного танцю, який в минулому приносив славу нашому народу далеко за межами України, а нині відходить у забуття.

Мета статті. Головною метою цієї роботи $\epsilon$ проаналізувати опис козацького танцю в творах українських письменників.

Виклад основного матеріалу. Мою увагу привернула робота під назвою «Запорізька січ колиска козацького танцю» Олександра Колоска (заслужений артиста України, профресор, лауреат міжнародних конкурсів, артист балету, балетмейстер і педагог). Це методичні рекомендації, в яких автор зібрав все, що пов'язане з українським козацтвом, і може стати чудовим поштовхом для більш детального дослідження, адже містить багато розділів. В своїй роботі О. Колосок розкриває як зародилось козацтво, якими були військові звичаї та січове життя, який вплив мала на козаків церква, яку функцію відігравали монастирі і де козаки здобували освіту.

Значну частину роботи автор присвятив козацькому танцю. Окрім еволюції та лексики танцю, надаються згадки про перші козацькі танці на театральній сцені (тобто, за яких обставин танець став народно-сценічним).

На думку О. Колоска, для дослідників народного хореографічного мистецтва можуть стати корисним матеріалом твори художньої літератури, в яких автори більшою чи меншою мірою вдаються до зображення картин танщю.

Значна кількість письменників та поетів (М. Гоголь, Т. Шевченко, Г. Квітка-Основ'яненко, M. Коцюбинський, I. Нечуй-Левицький та ін.) у своїх творах створити повноцінний образ героїв, відтворили події, надаючи їм історичної вірогідності. Це стало можливим завдяки вдало наведеним відомостям про танщі українського народу.

В поемі I. Котляревського "Енеїда» зустрічаємо згадки про український козацький танець [3]. Особливо яскраво зображено в ній танець головного героя. «Назву танцю не вказано, однак можна зрозуміти, що йдеться про популярний, можливо ще з часів Петра Сагайдачного, невіддільний від побуту запорозького козацтва танець «Козак» [2, с. 29].

Еней, матню в кулак прибравши

I не до соли промовлявши,

Садив крутенько гайдука...
У даному випадку «гайдук» - це окремий рух широко відомого колись танцю. «До поеми I. Котляревський додав словник малоросійських слів, в якому є пояснення виразу "садить гайдука» тобто танцювати навприсядки. Танцюристи для зручності підбирали поли одягу, який заважав у танці («матню в кулак прибравши»). До того ж, Еней «не до соли промовлявши» - тобто його танець супроводжувався вигуками, можливо й не зовсім пристойними» [2, с. 29].

Про часи запорозького козацтва часто йдеться у творах Т. Шевченка, які відомі поету з розповідей старших людей та історичних джерел. В поезї Шевченка козаки - це кращі представники українського народу, його захисники. Ïх максималізм (в усьому) яскраво показано в поемі «Гайдамаки» [6]. «Тут козаки танцюють під спів кобзаря, переносячи важкі вози, танцюють після здобуття перемоги на майдані у Лисиці. Навіть сліпий кобзар, який супроводжує козаків, танцює під акомпанемент Залізняка, піднімаючи куряву постолами» [2, с. 30].

Добре! добре! Ну, до танців, До танців, кобзарю!

Сліпий вшкварив - навприсядки Пішли по базару...

Зображення козацьких танців можна зустріти і в інших творах поета. В поемі «Чернець» Т. Шевченко змальовує характерний танець в русі (в просуванні) [6]. Щоб ніхто не бачив фрізичної кволості січових дідів (так називали на Січі старих козаків), вони кидали Січ і йшли або в поле вмирати, або в монастир. Група козаків приїхала із Запорізької Січі до Києва, супроводжувати свого старого побратима після козакування в монастир. Не просто йде, а прощаючись з вільним життям і товариством востанне від душі танцює:

В червоних штанях оксамитних Матнею улицю мете.

Іде козак. - Ох, літа! літа!

Що ви творите? - На тоте ж

Старий ударив в закаблуки,

Аж встала курява! Отак!

Та ще й приспівує козак...

Аналогічна сцена зустрічається в творах М. Кропивницького [4]. У драмі «Глитай, або ж павук» парубки йдуть 3 поля. «Один 3 них пропонуе: "Ану, затинай «Дуба". Чи дотанцюю до села" - i почав..., та навприсядки, то тропака утне, то зальотним рухом кругом ходить» [2, с. 30]. Решта хлопців співає:
Ой, дуб-дуба-дуба,
Дівчино моя люба,
Набрехали на мене.
Що я ходив до тебе.

Драматичні твори М. Кропивницького рясніють сценами танців молоді села і невимушених гуртових забав. Вони дають нам змогу уявити, які козацькі танці побутували в певний час, що мали особливого в своїй композиції та основних рухах. Козацьий танець автор зображував як герць (змагання). Суперники вільно рухалися на визначеній ними площі. Їх рухи змінювались від легких до більш складних. Можливі були такі моменти: поки один козак демонструе свої вміння, інший дивиться і готуе своєму супротивнику 
більш складнішу відповідь. Тут виконували присядки, колеса, щупаки, дрібні перебори та різноманітні чудернацькі стрибки [2].

У творах М. Кропивницький «Пропала грамота» і «Татарівна» згадуються козацькі танці «на заклад», що беруть свій початок із часів Запорозької Січі. «Це танці-суперечки («хто кого») хлопця 3 хлопцем, хлопця 3 дівчиною, музиканта 3 танцюристом. Іноді це просто вияв емоцій, що переповнюють виконавця» [2, с. 31].

У повісті «Дві московки» I. Нечуя-Левицького також зображено танець «Козак»: «Як орли на сірих вуток, як яструби на сизих голубів, налітали парубки - розганяли дівчат, як полохливих ластівок, і починали козака. Загула, застогнала земля під козацькими підковами! Орють землю закаблуками, рвуть траву зелену 3 корінням підкови! А хлопщі, взявшись в боки, закинувши шапки набакир, то підуть навприсядки, то задріботять ногами, то вдарять тропака, то знов плеснуть в долоні, знов підуть навприсядки, аж земля стугонить. Розмахують руками, розкидають ногами, а од свисту аж у вухах лящить!» [5, с. 40].

О. Колосок вважає, що М. Гоголь переконливо змалював запорожців у своїй повісті «Тарас Бульба»: «коло молодого запорожця четверо старих виробляли досить дрібно своїми ногами, кидалися, як вихор, вбік, мало не на голову музикам, i раптом, присівши, неслися навприсядки й били круто і міцно своїми срібними підковами твердо вбиту землю. Земля глухо гула на всю околицю, і в повітрі далеко лунали гопаки і тропаки, вибивані дзвінкими підковами чобіт. Та один жвавіше за всіх вигукував і летів слідом за іншими в танщі... До танцюристів приставали інші, i не можна було бачити без внутрішнього зворушення, як усе вибивало танець, найвільніший, найнесамовитіший, який тільки бачив коли-небудь світ, і який, за його могутніми творцями, названо козачком» [1, с. 236]. Танець старих, але моторних і бравих козаків головні герої (Тарас і його сини) спостерігали, прибувши на Січ.

Висновки i пропозиції. Підсумовуючи вище сказане бачимо, що в художніх творах відображено танцювальну культуру українського народу. Вони заслуговують на більш ретельніше вивчення, бо є джерелом знань про життя українського народу та багатства його духовної культури. Олександр Колосок зібрав у своїй роботі «Запорізька січ - колиска козацького танцю» всі складові життя українського козацтва разом. Чудовим $є$ те, що він звертає увагу на згадки про козацьке життя і дозвілля у художній літературі. Завдяки їм можна знайти чудові образи козаків і неповторне виконання рухів козацьких танців для сценічних постановок.

\section{Список літератури:}

1. Гоголь М.В. Програмні твори. Обереги. 2000. С. 351.

2. Колосок О.П. Запорізька січ - колиска козацького танцю. Методичні реколендації. 2004. С. 47.

3. Котляревський І.П. Енеїда. Поели, п’еси. 2005. С. 350.

4. Кропивницький М. Вибрані п'еси. Мистецтво. 1977. С. 366.

5. Нечуй-Левицький І.С. Твори в двох томах. Наукова дулка. 1985. С. 637.

6. Шевченко Т.Г. Кобзар. Просвіта. 2006. С. 344.

\section{References:}

1. Gogol M.V. (2000) Software works [Prohramni tvory]. Oberehy, p. 351.

2. Kolosok O.P. (2004) Zaporizhzhya Sich is the cradle of Cossack dance. Guidelines [Zaporiz'ka sich - kolyska kozats'koho tantsyu]. Metodychni rekomendatsiyi, p. 47.

3. Kotlyarevsky I.P. (2005) Aeneid [Eneyida]. Poemy, pyesy, p. 350.

4. Kropyvnytsky M. (1977) Selected plays [Vybrani pyesy]. Mystetstvo, p. 366

5. Nechuy-Levytsky I.S. (1985) Works in two volumes [Tvory v dvokh tomakh]. Naukova dumka, p. 637.

6. Shevchenko T.G. (2006) Kobzar [Kobzar]. Prosvita, p. 344 